\title{
Development of Curriculum Management For Basic Education Based Multicultural
}

\author{
Imron Arifin \\ Administration of Education, Faculty of Education \\ State University of Malang \\ Malang, Indonesia \\ imron.arifin.fip@um.ac.id
}

\begin{abstract}
Indonesia is a diverse country, rich in culture, made up of many tribes and Indonesia are united by the adage "Bhineka Tunggal Ika" (Unity in Diversity). Basic education have the major role in developing quality human resources. Management of basic education based multicultural indispensable, where basic education is the determination of the basis of knowledge, attitudes, skills useful for self-learners appropriate developmental level. Students early are directed able to respect, accept and respect the differences that arise around them and are taught to be able to extract meaning in the diversity happening around them. Multicultural education curriculum must be dynamic, and will always develop in accordance with the cultural diversity that developed at that time. Application-based multicultural curriculum at the basic education level should be disseminated among the environment. Values based multicultural education be understood by the entire academic community of the school, resulting in basic education environment reflected a multicultural culture that puts a high tolerance among individuals.
\end{abstract}

Keywords: curriculum management, basic education, multicultural

\section{INTRODUCTION}

Indonesia is a diverse country, rich in culture, made up of many tribes, and has its own peculiarities. Indonesia also consist of a multi-ethnic, but Indonesia is united with the slogan "Unity in Diversity" (different but still one) [1] [2]. The diversity that occurred in Indonesia can be a fortune because it can foster togetherness, unity, fraternity, nationality. However, it is also a challenge that is quite serious, such as ethnic conflict, religion, and race, ethics and morality are low, fragile honesty, the rule of law which is less than the maximum, as well as drugs and crime prolonged [3].

Today the Indonesian nation to face the challenges that are external and internal. External challenges include: (1) increasing the flow of information and global communication requirements and fast; (2) the emergence of mindset, orientation and lifestyle are more individualistic, hedonistic, exclusivism, and declining civility; (3) the enactment of free trade with the fierce competition, marked by a flood of automotive products and electronics from Japan, South Korea, Taiwan, and China; (4) a wide area and a strategic geographical location makes Indonesia as a bone of contention island with Malaysia, target of international drug trafficking, the influence of radicalism and terrorism, human trafficing, and transit of illegal immigrants who will be asked for asylum in Australia and other neighboring countries. While internal challenges, among others: (1) decreased ethics and moralita marked with crimes of corruption, crime, murder, drugs and immoral, despite its declining work ethic, courtesy, fairness, and the rule of law; (2) decreased sense of nationhood, unity and togetherness marked by rampant ethnic conflict, religion, politics, race for plantations and mining, and territorial; and (3) the rise of radicalism and terrorism in the incitement of ethnic, religious, and class [4].

Furthermore, to overcome internal and external challenges it is one of the efforts is through education, particularly based multicultural education [4]. Multicultural education is needed for the people of Indonesia have the high diversity, ranging from the social, cultural, religious, political aspirations, economic capacity, thus directly or indirectly such diversity bepengaruh on the ability of school / madrasah and capabilities of human resources (teachers) in implementing the curriculum [5]. The diversity of schools affect the ability of their students in the learning process, and contribute to the implementation of basic education curriculum [1] [2]. It is very important to be pursued, because education-based multicultural is one solution to increase human resources dignified, and create a sense of unity that is high for the creation of harmony, harmony and togetherness among the components of the nation [4] [5] [6] [7] [8] [9].

Primary education requires a process to develop oneself both from the view of life, attitude to life, and life skills, so we need a management curriculum that is able to predict the diversity of students who will follow a basic education, which in the curriculum focuses on the high tolerance of diversity a culture that is around us [1] [3] [6]. Multicultural education has a 
principle of equity pedagogy, which focuses on human equality, to remain principled in life, by the mastery of science as well as possible, and be open to new development and diversity in modern life [6] [10].

Based on the diversity that occurred in Indonesia, which is able to influence the process of education, the schools or madrasah need to think about alternative multicultural education, and the strategies and concepts of education based on the utilization of the diversity that exists in society, particularly that of the students, and teachers should have the the ability to embed the core values of multicultural education: democracy, humanism, pluralism or embed diversity in understanding and appreciating the followers of other religions and beliefs [2] [3] [4] [6] [10] [11].

Suniti, Hastuti, and Sonhadji provides the same opinion that multicultural education in Indonesia requires hard work in practice, where the process requires academic thinking and cultural analysis on Indonesian society pluralist, in order to achieve an increase in the degree of human and humanity, dignity and character to build the nation towards a high civilization [1] [4] [10]. Multicultural Education in basic education process requires a whole school / madrasah in preparing students, and placing students at the center of all activities of school practices that promote a variety of perspectives and appreciation of the diversity of cultures, languages, and religions in a democratic society [10].

Education is very influential on the development of the physical, intellectual, religious, moral, social, emotional, knowledge and experience of learners [12]. Basic education is the foundation stone for the level of education Elementary School / Islamic elementary schools) and Junior High School / MTs for the continuation of the existing levels on it. Has an elementary education major role in developing quality human resources [12]. Primary education has the responsibility to educate learners to behave and respect differences among people of diverse, therefore indispensable curriculum based on multicultural [1].

Multicultural education is one of the processes in an effort to develop aspects in a person, the view of life, attitudes and life skills, which process focuses on how a life of respect, sincere, and tolerant of the diversity of cultures that exist in the midst of society high level of plurality, so that learners have an awareness and understanding of widely manifested in tolerance [1] [2] [6].

Concepts based multicultural education is guided by the views of cultural pluralism and multiculturalism, which is a view looking individuals or groups in a society respectful of cultural diversity. Based multicultural education is the transmission of values, Development of multicultural education can be done through the addition of multicultural, where the provision of material actualization of the various cultures that exist in the country and the various cultures in the world, so that all areas can be charged multicultural studies. Field of multicultural studies can also be given as a separate field of study or subjects stand-alone, or can take the form of a practical program of educational institutions. Multicultural education curriculum can be used as a school-related experiences of ethnic groups, is a program that includes multicultural experience, and a design to improve fairness cultural groups, ethnic, and economic [1] [13].

Development of multicultural in the school can be done with motion equations, where the movement is seen as the real activities rather than discussed in scientific forums, and multicultural serve as a process that aims to foster a sense of social justice, equality, democracy, tolerance, and respect for human rights man is not easily achieved, so the need for livelihood or familiarization in all of the school community [11] [13].

Multicultural education is expected to enhance the learning opportunities of students, develop students' ability to identify the diversity that surrounds students, teach students to not discriminate against certain groups, established a good relationship between the environment at home and school, students are taught how to troubleshoot problems that occur around they are to continue to promote tolerance of diversity that occurs in environments with solutions that remain creative [1] [4] [11]. Sonhadji stated that based multicultural education program is recommended for the management shall determine the criteria clear and open in reception of teachers and employees, does not favor a particular ethnic group or, and delivering fair for teachers, students and parents [4].

\section{MULTICULTURAL CURRICULUM}

The curriculum is an educational plan that provides guidelines and a handle on the type, scope, sequence of content, as well as the educational process, so that the center of the curriculum used in an educational process, namely as a guide and grip the teacher in the learning process. Indonesia's diverse society requires a curriculum that is capable of supporting the process protege human being democratic, and emphasizing appreciation of life and reflection to be fully human, the generation that not only clever (superior knowledge), but also moral and ethical, can live in an atmosphere democratic, and respecting the rights of others [1] [6].

Curriculum-based multicultural own advantages, which the participants faced with various challenges, threats, obstacles or interference encountered in social life [1] [2] [4]. The purpose of the model-based multicultural curriculum in its application may change from year to year according to the needs that occur in the future [1] [6].

The application of the model-based curriculum multicultural expected to build learners more sensitive to the social environment in which there are various cultures are always dynamic evolving, students are expected to mature in facing various problems such as the looming challenges and 
opportunities that occur in the community and is always ready to see and understand developing issues in social life [1] [4] [8].

Principle-based multicultural curriculum development should see a cultural diversity becomes the basis for determining the philosophy, theories, models, and the relationship of the school with the local socio-cultural environment. Diversity of cultural that used as a basis for developing a curriculum component that includes: objectives, content, process and evaluation, where the existing culture within the education unit used as a source of learning and the object of study is used as a medium or media in developing learning activities of students at once schools to help preserve the local culture and national culture [1] [6].

Multicultural curriculum requires methods and designs in the achievement of its objectives, among them to learn in groups, learning centered on the environment, and the pattern of education "organization wheels". Flocking is a learning method selected in this curriculum, if possible in a group have the diverse culture, ethnicity, gender or religion different, resulting in a process of interaction between learners, and processes are not competitive, but the emphasis on the process of cooperation, understanding and consensus, Learning is also focused on diverse environmental culture, so that students get used to pressing social problems [1].

Methods based multicultural curriculum implementation will succeed if the support and active participation of parents, academicians, students, and communities [6]. The pattern of multicultural education need to put the main theme in the middle with some elaboration surrounding the main theme, which then need to be evaluated which covers all aspects of the abilities and personality of students, in accordance with the purpose and content is developed, with evaluation tools such as portfolios, records and interviews, where the use of evaluation tools adapted to the purpose and nature of the information collected [1].

\section{DISCUSSION}

Basic education in Indonesia aims to give the provision of basic capabilities to students aged 0-15 years in the form of knowledge, attitudes, skills useful for self-learners appropriate level of development, and were able to prepare them to pursue higher education [12]. Basic education is one of education, formal, so education must be clearly capable of acting to form students to be qualified in terms of knowledge, attitudes and behavior in accordance with the demands of the prevailing [1], hence the need to implementation of education-based multicultural since early, so they will be familiar with the life that promote tolerance and harmony of life amid the cultural diversity [8] [11].

The achievement of learners based multicultural, it would require the cooperation of all parties, so that the principal and the entire academic community in delivering learning requires a set of components, which need to be laid out starting with the vision, mission and educational goals, students, teachers and education personnel, curriculum, teaching and learning, educational facilities, educational management in schools, the external environment education. Each component of basic education has the function, purpose, and a different role, but in practice must be interconnected and support for the achievement of educational goals that have been formulated [2] [11] [12].

In shaping the curriculum based on multicultural, it is necessary to pay attention to the values, such as: giving students the opportunity to reach their potential, giving students the ability to learn how to learn and think critically, to encourage students to be active and play a role in education has done by bringing the stories and experiences to within the scope of student learning, students are given the freedom to demonstrate a variety of learning styles, and appreciate other groups who have contributed to our knowledge base, and constantly develop positive attitudes about different groups of himself. In a multicultural curriculum to instill all of the school community as citizens, citizens and the world community are good, and always learn to appreciate and evaluate knowledge from different perspectives, and continue to develop the identity of ethnic, national, and global. Students are always given the opportunity and stimulus in taking decisions and critical analysis skills so that students can make better choices in their everyday lives [1] [13].

Curriculum multicultural require screening in the material, which include things cultural that is based on the science of today, the subject matter of discussion must present the diversity and unity within and across groups, should be in the context of time and place, the material is able to give priority to deepen in addition to flexibility, the material shows the perspective of multicultural incorporated into the entire curriculum, treated as construct a social and therefore are tentative, the materials describing the experience and knowledge experienced by students to bring to class, pedagogy is always associated with a number of learning how to teach interactive in order to increase understanding, testing controversy, and mutual learning [1] [2].

Management based curriculum multicultural good is indispensable for running the educational process in basic education, which organized and planned to launch the process of learning under the guidance and responsibility of the school or educational institution and its faculty, where students are trained to have values that are able to respect, accept and respect the differences that arise among different ethnic groups. Students have the strong sense of unity, in the midst of ethnic diversity, even able to extract meaning from the existing differences [2] [7] [11].

Management based curriculum multicultural basic education, it is very dynamic, as adjusted and continues to develop in accordance with the development of multicultural in that period, hence the development of curricula based 
multicultural require surveys were critical to society, the study of the relationship between individuals or between groups with diverse backgrounds (race, ethnicity, religion, gender, culturally diverse). Based curriculum development multicultural required to conduct a study of the historical background and development trend of the attitude of solidarity, tolerance, or the development of discriminatory attitudes and social dynamics that occur in multicultural society, accompanied also the evaluation of the whole plan and criteria on the fulfillment of the interests of the majority of learners [1] [8].

In the curriculum required to use the Indonesian language is good and true, do grouping students fairly, and make rules about how to sit, how to talk, how to get along. Management of compulsory education to understand the background of the students well, accept students openly and can work with all parties. Students are required to be polite to anyone, and obey the school rules, as well as in social relationships did not differentiate the treatment of parents and community members, and establish good cooperation with the local community [4].

Management of the basic education curriculum based on multicultural, the development needs to change the philosophy of the curriculum of which apply uniformly to the philosophy more in line with the goals, objectives, and functions of each level of education and education unit, where the basic education requires a curriculum that is both humane, progressivism, and reconstruction social more emphasis on human capacity building effort for the students as individuals and as members of society, nation and world. Curriculum content should be the substantive aspects which contains facts, theories, and generalizations to the notion that include values, morals, procedures, processes, and skills that must be possessed of learners. Learning theory used in the curriculum multicultural should pay attention to the diversity of social, cultural, economic, and political, which puts students as social creatures, culture, politics and life as an active community of society, nation and world [1] [8].

The process of learning in a multicultural curriculum, must use a method of learning groups and compete in groups in a positive situation, and no longer is individual. With the hope of being able to make way in which the students are familiar with the diversity of cultural, social, intellectualistic, economic, and political aspirations [8] [14]. The process of curriculum traversed, then need to be evaluated include overall viability and personality of students, in accordance with the purpose and content is developed, where the evaluation tools used vary according to the nature of interest and information to be collected in accordance with application-based assessment grade (United Nations) with its varieties such as portfolios, notes, observations, interviews, performance test, project, and product [14].

The role of the evaluation of the basic education curriculumbased multicultural should include several important points, where the evaluation as a moral judgment, evaluation and follow-up in the decision making, where evaluation shows scale of moral values that do a comprehensive review of learners includes cognitive, affective, psychomotor with techniques varies [10].

\section{CONCLUSION}

Management of the basic education based on multicultural indispensable, where basic education is the determination of the basis of knowledge, attitudes, skills useful for self-learners appropriate level of development, and were able to prepare them to pursue higher education, where from an early age students are directed is able to respect, accept and respect the differences that emerged around them and the students are taught to be able to take on the meaning of diversity is going on around them.

Multicultural education curriculum must be dynamic, and will always develop in accordance with the cultural diversity that developed at that time, so that the diverse local identities is a charge that must exist in a multicultural education curriculum at the primary level.

Application-based multicultural curriculum at the primary level should be disseminated among the school environment or seminar and workshop curriculum based on multicultural followed by the academic community. Values based multicultural education be understood by the entire academic community of the school, resulting in a primary school environment reflected a multicultural culture that puts a high tolerance among individuals. Then the school management needs to pay attention on learning tools that support the curriculum, where the modules, textbooks, audiovisual media or other media used to support school-based curriculum can multicultural consumption with specifically design for learners.

Based management prioritizes to synergies of multicultural curricula, social activities that are all around, administrative support, staff training on the application of the values of multicultural education, so that the expected life of diverse cultures can run dynamically.

\section{REFERENCES}

[1] Suniti. 2014. Kurikulum Pendidikan Berbasis Multikultural. Jurnal Edueksos. Vol. 3., No. 2., Juli-Desember 2014.

[2] Wuryandani, W. 2010. Pembelajaran Berbasis Multikultural di Sekolah Dasar untuk Mengembangkan Karakter Bangsa. Yogyakarta: Universitas Negeri Yogyakarta.

[3] Arifin, I. 2015. Pendidikan Multikultural Perspektif Keagamaan dan Kultural. Dalam Sunandar, A. Prof. Son Sang Pendidik Multikultural. Malang: Intelegensia Media.

[4] Sonhadji, A. 2015. Membangun Peradaban bangsa dalam perspektif Multikultural: Potensi Indonesia menjadi Negara Besar. Malang: Universitas Negeri Malang.

[5] Arifin, I. 2016a. Islam Nusantara: Sejarah, Perkembangan, dan Kontroversinya. Proceeding Seminar Nasional "Islam Nusantara Meneguhkan Moderatisme dan Mengikis Ekstrimisme dalam Kehidupan Beragama." Malang: LP3 Universitas Negeri Malang. 13 Februari 2016. 
[6] Mostafazadeh et al., 2015. Analysis of Multi-Cultural Education Concept in Order to Explain Its Components. Journal of Education and Practice, Vol.6, No. 1.

[7] Banks, J. 1993. Multicultural Education: Development, Dimensions, and Challenges. The Phi Delta Kappa International, Vol. 75. Issue 2., September, 1993.

[8] Tandapai, et al. 2016. Education In Harmony Multicultural Society "Tana Poso". International Journal of Scientific \& Technology Research, Vol. 5, Issue 05, May 2016.

[9] Arifin, I. 2016b. Da'wah Management of The Wali Songo Socio-CulturalReligious Heritage of Nusantara Islamic in Indonesia. Proceeding of The 1st International Conference on Humanities and Social Sciences. Malang: LP2M of State University of Malang. September, 3, 2016
[10] Hastuti, T. B. 2015. Pengelolaan Pendidikan Multikultural di SD Negeri 02 Bejen Karanganyar. Surakarta: Universitas Muhammadiyah Surakarta.

[11] Bukaliya, R. \& Barbra, M.. 2014. Multiculturalism In School: An Appreciation From the Teachers' Perspective of Multicultural Education in the Zimbabwean School System. International Journal of Humaninities Social and Education, Vol. 1, Issue 2, February 2014

[12] Suharjo. 2006. Mengenal Pendidikan Sekolah Dasar. Jakarta : Departemen Pendidikan Nasional Direktorat Jenderal pendidikan Tinggi dan Direktorat Ketenagaan.

[13] Sutarno. 2008. Pendidikan Multikultural. Jakarta: Direktorat Jendral Pendidikan Tinggi Departemen Pendidikan Nasional.

[14] Naim, Ng, dkk. 2008. Pendidikan Multi Kultural. Jogjakarta: Ar-Ruzz Media. 